Article

\title{
A Cross-Cultural Adaptation and Validation of a Second-Language (L2) Motivation Instrument in South Korea
}

\author{
Weonjin Shin *, Fuhui Tong ${ }^{D}$, Hsiang-Yu Chien and Myeongsun Yoon \\ Department of Educational Psychology, College of Education and Human Development, Texas A\&M University, \\ College Station, TX 77843, USA; fuhuitong@tamu.edu (F.T.); johnny.chien@tamu.edu (H.-Y.C.); \\ myoon@tamu.edu (M.Y.) \\ * Correspondence: tetiss35@gmail.com
}

Citation: Shin, W.; Tong, F.; Chien, H.-Y.; Yoon, M. A Cross-Cultural Adaptation and Validation of a Second-Language (L2) Motivation Instrument in South Korea. Sustainability 2021, 13, 10333. https:/ / doi.org/10.3390/su131810333

Academic Editor: Jesús-Nicasio García-Sánchez

Received: 20 July 2021

Accepted: 10 September 2021

Published: 16 September 2021

Publisher's Note: MDPI stays neutral with regard to jurisdictional claims in published maps and institutional affiliations.

Copyright: (c) 2021 by the authors. Licensee MDPI, Basel, Switzerland. This article is an open access article distributed under the terms and conditions of the Creative Commons Attribution (CC BY) license (https:/ / creativecommons.org/licenses/by/ $4.0 /)$.
Abstract: In this research, we tested the psychometrics of a translated and adapted second language learning motivation instrument among Korean English learners. A total of 1373 college students from 9 universities and 11 majors in South Korea responded to the questionnaire. After the content validation, back-translation, and pilot study, 12 factors and 76 items were chosen for further construct validation. The data were then analyzed using Exploratory Factor Analysis (EFA) and Confirmatory Factor Analysis (CFA). Through EFA, 11 factors and 55 items were extracted while CFA analysis indicated good fit $(\mathrm{CFI}>0.9, \mathrm{SRMR}=0.05$, RMSEA $<0.05)$ of the measurement model. The results of this study showed acceptable psychometrics properties of questionnaire which is culturally and structurally appropriate in a Korean college context.

Keywords: EFL motivation; questionnaire validation; exploratory factor analysis; confirmatory factor analysis; L2 motivational self-system; Korean college student

\section{A Cross-Cultural Adaptation and Validation of L2 Motivation Instrument in South Korea}

Since English has rapidly become a global language [1], English language learning has drawn extensive attention in non-English speaking countries like South Korea, where it was descried as "English fever" [2]. In fact, most college students in Korea are expected to continue learning English to prepare for their future career or academic advancement in spite of 12 years of mandatory English curriculum in K-12, and as high as $40 \%$ of them have received private tutoring or attended afterschool private institutions [3-5].

With this strong emphasis on English language learning, motivation is considered one of the key factors in L2 learning process for EFL learners [6]. Dörnyei [7] indicated that motivation was one of the different individual features which could lead L2 learners learning the target language and stimulate them to be involved in the learning process. Moreover, second language acquisition (SLA) researchers have focused on L2 motivation since it seems related to L2 learner's effort, persisting in language learning, and their L2 learning outcome [8].

For that reason, Tong et al. [9] indicated that understanding students' motivation and strategies in language learning is important for observing students' L2 learning process and will provide guidance on how to improve the quality of language education. However, many instruments that measure learning motivation or similar constructs were developed in English language and validated in an English-speaking, Western setting, and the cross-cultural transferability of these instruments have not been fully addressed to be administered to learners whose native language is not English and who study in a non-English setting [9]. Therefore, there is a need for a solid instrument which is culturally and structurally appropriate to measure language learners' motivation in their native language. 
Although researchers have validated L2 motivation instrument for measuring learners' language learning process, e.g., [10-13], little research has been conducted to validate L2 learning motivation instrument in a Korean context where the "English fever" exists. Therefore, the purpose of this research is to translate and validate L2 learning motivation instrument to examine the cultural and structural adaptation in measuring English learning motivation in a Korean context.

\section{Literature Review}

\subsection{Previous Studies of Instrument Validation on L2 Motivation}

Current literature offers some knowledge about instrument validation on L2 motivation, e.g., [14,15]. For example, Teimouri [14] studied L2 motivation and behaviors among Iranian junior and senior high school within L2 motivational self-system frame from Dörnyei. The researchers performed Principal Component Analysis (PCA) and Cronbach's $\alpha$ to validate the instrument adopted from other studies [16,17]. Lau [15] validated Chinese Reading Motivation Questionnaire (CRMQ) using EFA and CFA for construct and initial validation. The results indicated that Hong Kong students' reading motivation was related to their strategy use, reading comprehension, and academic achievement.

To scope into L2 motivation instrument validation studies in Korean context, Kim and Kim [18] explored perceptual learning styles, L2 learning motivation, and English proficiency in Korean context. Participants included 2239 Korean EFL learners from grades 3 to 12. Questionnaires were adopted from Cohen and Oxford [19], Kinsella [20], and Al-Shehri [21]. For content validity, two experienced elementary school teachers reviewed the questionnaire and modified it according to the level of students, and the researchers conducted a pilot study as well. Through CFA, the authors concluded that perceptual learning styles indicated satisfactory goodness of fit which indicated they are intercorrelated with discriminant validity.

Kim and Kim [22] studied L2 learners' resilience and its relationship with motivated behavior and language proficiency in English language learning. A total of 1620 secondary school participants were recruited from 11 schools in South Korea. The adopted 26 items came from Shin, Kim, and Kim [23] for resilience and 5 items from Taguchi et al. [16] for motivated behavior and self-reported proficiency. Kim, Kim, and Kim [24] analyzed the data through varimax EFA, internal consistency reliability, CFA, and regression analysis. They found five factors for resilience through EFA and a well-established measurement model through CFA.

Finally, Lee and Lo [25] investigated the relationship among classroom language choice, student's motivation of language learning, and proficiency. A total of 366 college students from South Korea participated in the study. The items from the questionnaire were adopted from other studies [26-29]. For L2 proficiency, they collected data from the speaking test of an English course and TOEIC scores. EFA was conducted to determine four factors: "attitudes toward English-only, attitudes toward classroom code-switching, ideal L2 self, and ought-to L2 self" [25], p. 126. Through this validation, they further conducted multiple regression analysis and reported that ideal L2 self is one of the predictors to attitudes toward classroom language choice.

\subsection{Cross-Cultural Translation and Adaptation of L2 Motivational Self System Questionnaire}

In the previous section we discussed L2 motivation instrument in general; in this section, we narrow it down to the questionnaire from Taguchi et al. [16]. Among previously mentioned L2 motivation instruments, the questionnaire from Taguchi et al. [16] is widely adopted and used for validation in EFL context. Many researchers adapted that questionnaire since it is well-designed for an EFL context, e.g., [30-36]. It has been translated and adopted in many languages such as Hungarian [37], Chinese [38], Japanese, [39], and Farsi [35]. The instrument has been widely cited (1007 times on Google scholar as of August 2021) and applied in studies in Saudi [32], Japan [33], South Korea [22,34], and Iran [35]. For example, Kim and Kim [22] adopted 5 items from the 31-item questionnaire from 
Taguchi et al. [16]. The study validated the items through varimax EFA and CFA. Kim and Kim [22] identified 26 items with 5 factors and satisfactory goodness of fit for CFA model. Overall, these researchers concluded that the questionnaire from Taguchi et al. [16] was well established in terms of validity and reliability in the EFL contexts.

\subsection{Rationale to Validate the Instrument in a Korean Context}

Although existing studies [22,26,34,40] have translated and adapted Taguchi et al.'s [16] instrument in Korean, we noticed that there is a need for fully a translated, adapted, and validated questionnaire from Taguchi et al. [16] in the Korean context for the following reasons. First, the translation and adaptation were not fully carried out in Korean and other contexts, because it (as well as previous studies in other languages) did not use L2MSS in its entirety. In our current study, we include all items from Taguchi et al. [16] including those that were not translated and validated from previous research. In addition, the hypothesized model we propose from this research also includes factors that the previous studies failed to include for validation from the original questionnaire of Taguchi et al. (2009). For example, Kim [26] explored the motivational self-system among Korean EFL elementary, junior high, and high school students using items from Kim [26] and Taguchi et al. [16]. Kim [26] selected 9 out of 16 factors from the original questionnaire. He reported internal consistency of the motivational construct but did not validate the instrument. Another study, Kong et al. [34], did not include all items from each factor either. Thus, these items were not validated in other research papers.

Third, the participants had a different background in previous research. In this research, the target population is Korean college students who learned English as a foreign language. Additionally, participants were more representative, ranging widely from geographic regions, not only Seoul (capital) but also other areas such as the Busan, Kyunggi, Jeonju, Chungchungbuk, and Chungchungnam Province. However, the participants from previous studies $[26,40]$ range from elementary to high school in metropolitan areas from South Korea.

Lastly, the other previous research did not conduct construct validation such as EFA, CFA, or SEM for their translated instrument for Korean EFL learners. Kim [40] examined the relationship between perceptual learning style and learner's motivational factors, but he did not conduct any construct validation on the instrument used in the study. Similarly, Kim [26] did not examine the instrument for construct validation using factor analysis. Although Kong et al. [34] performed factor analysis, the items in their validation were not complete from each of the original factors. Finally, Kim et al. [22] adopted five items from instrument of Taguchi et al. [16] which is about motivated behaviors and validated through varimax EFA and CFA. However, they only included five items from the original instrument which is not a full validation.

In sum, there has been a lack of thorough validation of questionnaire in the aforementioned studies, especially in Korean context. Some earlier studies did not fully include the questionnaire items for validation from their study, i.e., [26,34], while others did not employ psychometric analysis such as EFA or CFA to validate the questionnaire in Korean context, e.g., [26]. To the best of our knowledge, the questionnaire from Taguchi et al. [16] has not been translated, adapted, and validated for college students in South Korea. Thus, the purpose of this research is to translate and validate the questionnaire from Taguchi et al. [16] among native Korean college students. Through EFA and CFA, we intend to examine whether the translated instrument is psychometrically and culturally appropriate to measure college students' L2 motivation in South Korea.

\section{Materials and Methods}

\subsection{Research Context and Participants}

To increase representativeness of participants, we recruited from nine universities in diverse locations in South Korea. Four universities are national universities and the others are private. All are four-year colleges except one which is a two-year college. By 
the time of their admission into college, these students have received regular English courses from elementary to high school since those are mandatory for all students in South Korea. This means that participants have most likely been learning English as a foreign language for $6 \mathrm{~h}$ per a week for 6 years in middle and high school level and $45 \mathrm{~min}$ per a week for 6 years in elementary level. Moreover, all of the universities offer English classes such as English conversation 101 or English writing. The participants' majors were diverse: science, education, linguistics, business, tour translation, law, nursing school, engineering, flight service, tourism, psychology, liberal arts, and health. In this research, a total of 1459 college students whose first language is Korean and who learn English as a foreign language in South Korea were invited to participate. Among them, data from 86 participants were eliminated due to the following reasons: outlier, partial answering, not targeted participants, and random answering. The final sample included responses from 1373 participants.

\subsection{Back Translation and Pilot Study}

We translated the English version of the questionnaire from Taguchi et al. [16] into Korean, which was then back-translated by a professional English-Korean translator. This back translation method has been studied by Brislin [41]; it provides functionally equivalently when the original language and the target language are studied. After that, two native Korean-speakers who are pursuing doctoral degrees at an English-speaking institution reviewed the questionnaire for content validity. An English major professor who is native Korean reviewed the contents of the items in relation to the cultural adaptation based on her prior experiences of teaching English to Korean college students. At this stage, ethnocentrism was eliminated because it was not an identified factor when Dörnyei [11] developed the questionnaire and it was irrelevant in our study of language learning motivation (e.g., other cultures should learn more from my culture). Based on the content validation process results, we also deleted the fear of assimilation factor because it was both irrelevant and not a suitable question for the purpose of the study (e.g., I think that, as internationalization advances, there is a danger of losing the (Korean) identity). Next, a pilot study was conducted with 15 Korean university students to read through the translation and provide feedback on the questionnaire regarding any ambiguity. This helps us decide that items from self-confidence and interest in the English language entail similar meaning with items from intended effort and attitudes on language learning. To avoid redundancy, both self-confidence and interest in the English language factors were removed. This method was also implemented by Lam et al. [42] and You and Dörnyei [38] when they validated content of the instrument for student engagement. In the end, four factors (i.e., linguistic confidence, ethnocentrism, fear of assimilation, and interest in the English language) were discarded and some items were modified or eliminated based on cultural differences, interest of this research, and appropriateness in Korean translation.

\subsection{Instrumentation}

The questionnaire included six demographic questions that captured participants' background such as gender, age, year of school, major, English proficiency, and study abroad experience. The instrument is on a 5-point Likert scale: $1=$ strongly disagree, disagree, normal, agree, and strongly agree. Both English and Korean version of questionnaires are provided in Appendix A and B. For L2 learning motivation, however, 4 out of 16 factors from Taguchi et al.'s [16] original instrument were removed after the content validation and pilot study: ethnocentrism, fear of assimilation, self-confidence, and interest in the English language. Thus, the final instrument contained a total of $12 \mathrm{~L} 2$ motivational factors with 76 items; "intended effort (10 items), ideal L2 self (10), ought-to L2 self (10), family influence (10 items) instrumentality-promotion (14), instrumentality-prevention (11), attitudes toward language learning (5), attitudes toward L2 community (4), cultural interest (4), integrativeness (3), travel orientation (3), and English anxiety (10)" (Taguchi et al., [16] pp. 74-75). 


\subsection{Data Collection and Analysis}

The 76-item questionnaire was administered during December 2018. We visited each school and explained the research and rules of participation verbally before the classes. It took about $15 \mathrm{~min}$ for the participants to complete the questionnaire in paper format. Data were then manually entered and verified into an Excel spreadsheet.

Exploratory factor analysis (EFA) and confirmatory factor analysis (CFA) were adopted to validate the translated instrument. EFA was appropriate to identify underlying structure among measured variables [42]. Among 1373 participants, data from 300 participants were randomly chosen for EFA and the remaining were used for CFA. According to CabreraNguyen [43] and Winter et al. [44], the minimum sample size of EFA is recommended to exceed 146 when the instrument has 11 factors with 76 items. We chose 300 for EFA following the criteria by Rouguette and Falissard [45] based on our number of items and factors. The purpose of the EFA is to locate the items to the factors so we assigned necessary sample size for EFA. The amount of 300 respondents is chosen based on the criteria followed by Rouguette and Falissard [45]. According to the study [45], 300 respondents who were randomly selected are sufficient for EFA based on our number of items and factors.

CFA is one of the analytical approaches of structural equation modeling (SEM), which allows researchers to examine the fit between the data and hypothesized model; it also yields modification indices to improve the model for a better fit $[46,47]$. CFA is multivariate statistical procedure which allows researchers to confirm the hypothetical model through parameter estimates, fit indices, and measurement invariance [47]. Generally, indicators used in CFA include standardized root mean square residual (SRMR) and root mean square error of approximation (RMSEA), which are recommended to be lower than 0.08 while comparative fit index (CFI) should be higher than 0.9 to indicate acceptable goodness of fit [48]. Thus, CFA is appropriate to facilitate hypothesized-model testing, comparison, and improvement [49]. The reliability of each factor was calculated in the form of Cronbach's $\alpha$. Besides Cronbach's alpha, this study also tested the McDonald's omega $[50,51]$ for the total scores and each factor. It provides the reliability information that included the correlations between items and the general factor. The corresponding omega coefficients were calculated through the function "omega" in the R package "psych" [52]. Mplus software program was used to analyze the data. Goodness of fit index (GFI) and comparative fit index (CFI) were calculated to index model fit. These indexes ranged from 0 to 1 where 0 means no fit and 1 means perfect fit [35]. A value more than 0.90 is considered as good fit [53]. Both RMSEA and SRMR smaller than 0.05 are good indicators of the model $[48,53]$.

\section{Results}

The demographic details are described in Table 1. Among the 1373 students, the number of female participants was slightly larger than male peers. The age range was between 19 and 34 .

\subsection{EFA to Generate L2 Motivation}

Three hundred participants were randomly chosen and the data used for EFA were through Mplus with oblique rotation. Items were removed from the factors if the value of factor loading was below 0.3 , which indicates a small loading [54]. The missing data was analyzed, and maximum likelihood estimation was calculated. 
Table 1. Descriptive statistics of participant's background.

\begin{tabular}{|c|c|c|c|c|c|c|c|c|c|c|c|}
\hline \multirow[t]{2}{*}{ School } & \multirow[b]{2}{*}{ Total } & \multicolumn{2}{|c|}{ Gender } & \multicolumn{2}{|c|}{ Age } & \multicolumn{4}{|c|}{ Year of School } & \multicolumn{2}{|c|}{ Study Abroad } \\
\hline & & $\mathbf{M}$ & F & Range & Mean & 1 & 2 & 3 & 4 & En & Non En \\
\hline 1 & 628 & 223 & 405 & $19-34$ & 26.5 & 47 & 247 & 207 & 127 & 62 & 8 \\
\hline 2 & 88 & 72 & 16 & $20-27$ & 23.5 & 0 & 20 & 67 & 1 & 9 & 0 \\
\hline 3 & 28 & 18 & 10 & $19-25$ & 22 & 9 & 7 & 5 & 7 & 8 & 0 \\
\hline 4 & 61 & 44 & 17 & $19-26$ & 22.5 & 56 & 1 & 3 & 1 & 4 & 0 \\
\hline 5 & 63 & 51 & 12 & $20-30$ & 25 & 0 & 51 & 11 & 1 & 5 & 1 \\
\hline 6 & 18 & 8 & 10 & $20-26$ & 23 & 0 & 16 & 0 & 2 & 3 & 1 \\
\hline 7 & 62 & 37 & 25 & $20-28$ & 24 & 1 & 24 & 18 & 19 & 6 & 3 \\
\hline 8 & 254 & 122 & 132 & $20-30$ & 25 & 5 & 45 & 103 & 101 & 29 & 17 \\
\hline 9 & 171 & 20 & 151 & $19-26$ & 22.5 & 158 & 13 & 0 & 0 & 25 & 6 \\
\hline Total & 1373 & 595 & 778 & $19-34$ & 26.5 & 273 & 424 & 414 & 259 & 151 & 36 \\
\hline
\end{tabular}

Out of the 12 factors, intergrativeness was not identified and some items were loaded in a different factor from the original questionnaire. There were three items $(71,72$, and 73$)$ which were not loaded on integrativeness. These items indicated low factor loadings $(<0.3)$ or were scattered randomly to other factors. Thus, these were eliminated.

Additional items were eliminated from their original factors due to small value (i.e., Item $2,7,38,40,41,43,44$, and 71). Furthermore, even the items that were loaded on other factors with value larger than 0.3 were removed if they neither theoretically nor structurally made sense (i.e., item 8, 50, and 73). For example, item 8 ("Compared to my classmates, I think I study English relatively hard" [16], p. 91) is loaded on attitudes on L2 language learning which was supposed to be loaded on intended effort. Item 50 ("Studying English is important to me, because I would feel ashamed if I got bad grades in English" [16], p. 91) is loaded on ought-to L2 self which is from instrumentation-prevention.

In cases when the item is loaded onto more than one factor, the item is only chosen to one factor which shows the highest value under the theoretical rationale (i.e., item 31, 64, and 70). To be specific, item 31("Being successful in English is important to me so that I can please my parents/relatives" [16], p. 93) was originally loaded onto family factor. However, this item was loaded onto both ought-to L2 self and family factors in our model. Item 70 originally belonged to the factor of anxiety but double loaded both on anxiety and ought to L2 self. However, item 70 is theoretically from the anxiety question and has higher value of factor loading on anxiety; therefore, we decided to keep it under the anxiety factor. Lastly, some items were removed if they were scattered randomly on factors (i.e., Item 30, 33,36 , and 39) since it is hard to tell which factor they actually measure. Therefore, a total of 11 factors and 61 items were identified and retained through EFA. The factor loadings from EFA are shown in Table 2.

Table 2. Factor loadings for exploratory factor analysis.

\begin{tabular}{|c|c|c|c|c|c|c|c|c|c|c|c|}
\hline Item & F1 & F2 & F3 & F4 & F5 & F6 & F7 & F8 & F9 & F10 & F11 \\
\hline 1 & 0.40 & & & & & & & & & & \\
\hline 3 & 0.54 & & & & & & & & & & \\
\hline 4 & 0.86 & & & & & & & & & & \\
\hline 5 & 0.78 & & & & & & & & & & \\
\hline 6 & 0.67 & & & & & & & & & & \\
\hline 9 & & 0.44 & & & & & & & & & \\
\hline 10 & & 0.57 & & & & & & & & & \\
\hline 11 & & 0.86 & & & & & & & & & \\
\hline 12 & & 0.94 & & & & & & & & & \\
\hline 13 & & 0.96 & & & & & & & & & \\
\hline
\end{tabular}


Table 2. Cont.

\begin{tabular}{|c|c|c|c|c|c|c|c|c|c|c|c|}
\hline Item & F1 & F2 & F3 & F4 & F5 & F6 & F7 & F8 & F9 & F10 & F11 \\
\hline 14 & & 0.85 & & & & & & & & & \\
\hline 15 & & 0.92 & & & & & & & & & \\
\hline 16 & & & 0.51 & & & & & & & & \\
\hline 17 & & & 0.71 & & & & & & & & \\
\hline 18 & & & 0.69 & & & & & & & & \\
\hline 19 & & & 0.70 & & & & & & & & \\
\hline 20 & & & 0.92 & & & & & & & & \\
\hline 21 & & & 0.87 & & & & & & & & \\
\hline 22 & & & 0.88 & & & & & & & & \\
\hline 31 & & & 0.61 & & & & & & & & \\
\hline 51 & & & 0.61 & & & & & & & & \\
\hline 24 & & & & 0.76 & & & & & & & \\
\hline 25 & & & & 0.74 & & & & & & & \\
\hline 26 & & & & 0.96 & & & & & & & \\
\hline 27 & & & & 0.81 & & & & & & & \\
\hline 28 & & & & 0.77 & & & & & & & \\
\hline 29 & & & & 0.56 & & & & & & & \\
\hline 32 & & & & 0.28 & & & & & & & \\
\hline 23 & & & & & 0.50 & & & & & & \\
\hline 34 & & & & & 0.72 & & & & & & \\
\hline 35 & & & & & 0.76 & & & & & & \\
\hline 37 & & & & & 0.49 & & & & & & \\
\hline 42 & & & & & 0.36 & & & & & & \\
\hline 49 & & & & & 0.39 & & & & & & \\
\hline 52 & & & & & & 0.89 & & & & & \\
\hline 53 & & & & & & 0.86 & & & & & \\
\hline 54 & & & & & & 0.95 & & & & & \\
\hline 55 & & & & & & 0.80 & & & & & \\
\hline 56 & & & & & & 0.72 & & & & & \\
\hline 57 & & & & & & 0.45 & & & & & \\
\hline 45 & & & & & & & 0.86 & & & & \\
\hline 46 & & & & & & & 0.97 & & & & \\
\hline 47 & & & & & & & 0.91 & & & & \\
\hline 48 & & & & & & & 0.54 & & & & \\
\hline 66 & & & & & & & & 0.83 & & & \\
\hline 67 & & & & & & & & 0.80 & & & \\
\hline 68 & & & & & & & & 0.98 & & & \\
\hline 69 & & & & & & & & 0.96 & & & \\
\hline 70 & & & & & & & & 0.62 & & & \\
\hline 58 & & & & & & & & & 0.51 & & \\
\hline 59 & & & & & & & & & 0.87 & & \\
\hline 60 & & & & & & & & & 0.82 & & \\
\hline 61 & & & & & & & & & 0.79 & & \\
\hline 72 & & & & & & & & & 0.37 & & \\
\hline 62 & & & & & & & & & & 0.69 & \\
\hline 63 & & & & & & & & & & 0.72 & \\
\hline 64 & & & & & & & & & & 0.60 & \\
\hline 65 & & & & & & & & & & 0.77 & \\
\hline 74 & & & & & & & & & & & 0.73 \\
\hline 75 & & & & & & & & & & & 0.87 \\
\hline 76 & & & & & & & & & & & 0.80 \\
\hline
\end{tabular}




\subsection{CFA to Generate and Modify L2 Motivation Model}

The L2 motivation model with 11 factors and 61 items were then subjected to CFA with data from the remaining 1017 participants. We used Mplus software with maximumlikelihood estimation. Results from CFA in Table 3 showed that the model fit of these 61 items was unsatisfactory (i.e., original model), because CFI is smaller than 0.9, SRMR is larger than 0.05 , and RMSEA is 0.05 which is marginally acceptable. To improve model fit, modification indices (MI) were examined. MI generated by Mplus provides a suggestion to improve the fit of the model, and a relatively high MI value indicates a need to make modification for the measurement model through [55]. Based on MI, the following changes were made.

Table 3. Fit indices of L2 Motivation on scales of L2MSS questionnaire (55 Items, 11 Factors).

\begin{tabular}{cccccc}
\hline Fit Statistics & $\chi^{2}$ & DF & CFI & SRMR & RMSEA \\
\hline $\begin{array}{c}\text { Original } \\
\text { model }\end{array}$ & $6441.94^{* *}$ & 1714 & 0.87 & 0.06 & 0.05 \\
$\begin{array}{c}\text { Revised } \\
\text { model }\end{array}$ & $4209.16^{* *}$ & 1372 & 0.92 & 0.05 & 0.04 \\
\hline Note $^{* *} p<0.01$. & & & &
\end{tabular}

First, items 9, 72, and 48 showed inconsistent loading in modification. Item 72 belongs to attitudes on community which was identified in EFA procedure but was suggested to be added onto instrumentation-promotional factor. Likewise, item 48 , which originally belonged to instrumentation-prevention factor, was suggested to be loaded onto instrumentation-promotion factor. These results, however, did not seem to be theoretically nor structurally sound. In addition, the standardized factor loadings of these items were relatively low as compared to other loadings. Thus, these items were removed.

Second, based on the modification indices, items 29 and 58 have inconsistent loadings. This caused problems due to the translation between original items into Korean context. Unlike other items from family influence, item 29 ("My parents/family believe(s) that I must study English to be an educated person" [16], p. 93) asks parent's opinion which is passive connotation to the participants. Other items from family influence ask the participants' opinion towards their parents (e.g., item 31: "Being successful in English is important to me so that I can please my parents/relatives" [16], p. 91). In the case of item 58 ("Do you like to travel to English-speaking countries" [16], p. 96), it asks itself both attitudes on L2 community and travel orientation. In addition, modification was found that this item can be loaded on travel factor instead of attitudes on L2 community. Due to the ambiguity of its meaning, these items were deleted.

Third, we found that there is dual meaning in item 32 ("I must study English to avoid being punished by my parents/relatives" [16], p. 93) based on cultural context of Korea. This item was suggested under both ought-to L2 self and family influence on a result of local fit. Originally it was loaded on family influence. However, it is sometimes hard to differentiate the motivation between ought-to L2 self and family influence since many Korean students are likely to feel pressure from their parents to study L2 for their academic or future career. Additionally, item 32 showed a small coefficient based on standardized model results relatively compared to other items loaded on each factor. Thus, this item was removed. The final version of the instrument contained 11 factors and 55 items. The overall model fit of the final model turned out to be satisfactory (Table 3). Table 4 is the coefficient table of CFA, indicating solid construct of measurement model. 
Table 4. Factor loadings of final CFA model and reliability.

\begin{tabular}{|c|c|c|c|c|c|c|c|c|c|c|c|}
\hline Items & Intended & Ideal & Ought & Family & InstrPro & Attlang & InstrPre & Anxiety & Attcom & Cultural & Travel \\
\hline Cronbach's $\alpha$ & 0.85 & 0.92 & 0.88 & 0.85 & 0.80 & 0.91 & 0.84 & 0.89 & 0.92 & 0.83 & 0.86 \\
\hline McDonald's $\omega$ & 0.84 & 0.92 & 0.77 & 0.84 & 0.74 & 0.90 & 0.84 & 0.83 & 0.90 & 0.82 & 0.86 \\
\hline 1 & 0.50 & & & & & & & & & & \\
\hline 3 & 0.73 & & & & & & & & & & \\
\hline 4 & 0.84 & & & & & & & & & & \\
\hline 5 & 0.77 & & & & & & & & & & \\
\hline 6 & 0.80 & & & & & & & & & & \\
\hline 10 & & 0.72 & & & & & & & & & \\
\hline 11 & & 0.85 & & & & & & & & & \\
\hline 12 & & 0.85 & & & & & & & & & \\
\hline 13 & & 0.80 & & & & & & & & & \\
\hline 14 & & 0.80 & & & & & & & & & \\
\hline 15 & & 0.79 & & & & & & & & & \\
\hline 16 & & & 0.52 & & & & & & & & \\
\hline 17 & & & 0.67 & & & & & & & & \\
\hline 18 & & & 0.67 & & & & & & & & \\
\hline 19 & & & 0.67 & & & & & & & & \\
\hline 20 & & & 0.78 & & & & & & & & \\
\hline 21 & & & 0.74 & & & & & & & & \\
\hline 22 & & & 0.76 & & & & & & & & \\
\hline 31 & & & 0.67 & & & & & & & & \\
\hline 51 & & & 0.61 & & & & & & & & \\
\hline 24 & & & & 0.73 & & & & & & & \\
\hline 25 & & & & 0.69 & & & & & & & \\
\hline 26 & & & & 0.86 & & & & & & & \\
\hline 27 & & & & 0.74 & & & & & & & \\
\hline 28 & & & & 0.68 & & & & & & & \\
\hline 23 & & & & & 0.60 & & & & & & \\
\hline 34 & & & & & 0.65 & & & & & & \\
\hline 35 & & & & & 0.73 & & & & & & \\
\hline 37 & & & & & 0.71 & & & & & & \\
\hline 42 & & & & & 0.74 & & & & & & \\
\hline 49 & & & & & 0.67 & & & & & & \\
\hline 52 & & & & & & 0.71 & & & & & \\
\hline 53 & & & & & & 0.79 & & & & & \\
\hline 54 & & & & & & 0.89 & & & & & \\
\hline 55 & & & & & & 0.89 & & & & & \\
\hline 56 & & & & & & 0.79 & & & & & \\
\hline 57 & & & & & & 0.68 & & & & & \\
\hline 45 & & & & & & & 0.75 & & & & \\
\hline 46 & & & & & & & 0.89 & & & & \\
\hline 47 & & & & & & & 0.80 & & & & \\
\hline 66 & & & & & & & & 0.73 & & & \\
\hline 67 & & & & & & & & 0.85 & & & \\
\hline 68 & & & & & & & & 0.90 & & & \\
\hline 69 & & & & & & & & 0.84 & & & \\
\hline 70 & & & & & & & & 0.56 & & & \\
\hline 59 & & & & & & & & & 0.88 & & \\
\hline 60 & & & & & & & & & 0.94 & & \\
\hline 61 & & & & & & & & & 0.84 & & \\
\hline 62 & & & & & & & & & & 0.80 & \\
\hline 63 & & & & & & & & & & 0.75 & \\
\hline 64 & & & & & & & & & & 0.69 & \\
\hline 65 & & & & & & & & & & 0.71 & \\
\hline 74 & & & & & & & & & & & 0.85 \\
\hline 75 & & & & & & & & & & & 0.76 \\
\hline 76 & & & & & & & & & & & 0.81 \\
\hline AVE. & 0.73 & 0.80 & 0.68 & 0.74 & 0.68 & 0.79 & 0.81 & 0.78 & 0.89 & 0.74 & 0.81 \\
\hline
\end{tabular}

Note. Intended: intended effort; Ideal: ideal L2 self; Ought: ought-to prevention; Family: family influence; InstrPro: instrumentalitypromotion; Attlang: attitudes toward language learning; InstrPre: instrumentality-prevention; Anxiety: English anxiety; Attcom: attitudes toward L2 community; Cultural: cultural interest; Travel: travel orientation.

According to the average factor loading of each construct (Table 4), most of them were above 0.7 , which suggested their convergent validity [56]. There were two constructs, Ought-to L2 self and instrumentality-promotion, that were marginally convergent vali- 
dated. This paper also compared the extracted covariance and the squared correlation between each factor to inspect the discriminant validity. When the extracted covariance is larger than the squared correlation coefficient, then these two factors are considered discriminant validated [56]. For example, the variance of intended effort and ideal L2 self were 0.25 and 0.7 , respectively, and the correlation coefficient of these two factors was 0.65 . The extracted covariance is calculated as the square root of the variance multiplied by the coefficient, hence $(0.65 \times \sqrt{0.25} \times \sqrt{0.7})$. Because 0.27 is less than 0.42 (Square of coefficient), there is no discriminant validity between these two factors. The result (the bolded variable pairs in Table 5) is provided. The discriminant validity of intended effort exists between ought-to L2, family influence, and instrumental-promotion. The discriminant validity of ideal L2-self exists with all constructs except anxiety factor. Ought-to L2 self does not have discriminant validity with instrumental-promotion. Family influence is discriminant validated with other factor but anxiety. The discriminant validity of instrumental-promotion is suggested with the rest of the factors. Attitudes towards language learning has discriminant validity with attitudes towards L2 community, cultural interest, and travel orientation. The discriminant validity of instrumental-prevention exists between anxiety, attitudes towards language learning, and travel orientation. Anxiety is not discriminant with the other factors. The discriminant validity of attitudes towards L2 community exists between cultural interest and travel orientation. In the end, it is discriminant validated between cultural interest and travel orientation.

Table 5. Correlation matrix of latent variables.

\begin{tabular}{|c|c|c|c|c|c|c|c|c|c|c|c|}
\hline & Intend & Ideal & Ought & Family & InstrPro & Attlang & InstrPre & Anxiety & Attcom & Cultural & Travel \\
\hline Ideal & $0.65^{* *}$ & & & & & & & & & & \\
\hline Ought & $0.23 * *$ & $0.22 * *$ & & & & & & & & & \\
\hline Family & $0.28^{* *}$ & $0.28 * *$ & $0.49 * *$ & & & & & & & & \\
\hline InstrPro & $0.35^{* *}$ & $0.29 * *$ & $0.61^{* *}$ & $0.33^{* *}$ & & & & & & & \\
\hline Attlang & $0.63^{* *}$ & $0.63 * *$ & $0.18^{* *}$ & $0.26 * *$ & $0.16 * *$ & & & & & & \\
\hline InstrPre & 0.01 & 0.02 & $0.44^{* *}$ & $0.30 * *$ & $0.40 * *$ & -0.06 & & & & & \\
\hline Anxiety & $-0.18^{* *}$ & $-0.28 * *$ & $0.19 * *$ & -0.07 * & $0.21 * *$ & $-0.31 * *$ & $0.28 * *$ & & & & \\
\hline Attcom & $0.49 * *$ & $0.58 * *$ & $0.20 * *$ & $0.25 * *$ & $0.25 * *$ & $0.55^{* *}$ & 0.01 & $-0.26 * *$ & & & \\
\hline Cultural & $0.45^{* *}$ & $0.55^{* *}$ & $0.13^{* *}$ & $0.19 * *$ & $0.23 * *$ & $0.53^{* *}$ & 0 & $-0.24^{* *}$ & $0.70 * *$ & & \\
\hline Travel & $0.47^{* *}$ & $0.54 * *$ & $0.30 * *$ & $0.28 * *$ & $0.44^{* *}$ & $0.43^{* *}$ & $0.11 * *$ & $-0.08 *$ & $0.58 * *$ & $0.51 * *$ & $1 * *$ \\
\hline Variance & 0.25 & 0.70 & 0.35 & 0.81 & 0.49 & 0.58 & 0.83 & 0.67 & 0.79 & 0.62 & 0.82 \\
\hline
\end{tabular}

Note1. Intended: intended effort; Ideal: ideal L2 self; Ought: ought-to prevention; Family: family influence; InstrPro: instrumentalitypromotion; Attlang: attitudes toward language learning; InstrPre: instrumentality-prevention; Anxiety: English anxiety; Attcom: attitudes toward L2 community; Cultural: cultural interest; Travel: travel orientation. Note2. ${ }^{*} p<0.05$; ${ }^{* *} p<0.01$. Note3. Bolded values means square $r$ was smaller than the variance extracted, which means the discriminant validities.

Finally, each motivation factor is strongly correlated with other motivational factors (Table 5) except instrumentality prevention with intended effort, ideal L2 self, attitudes towards language learning, attitudes towards L2 community, and cultural interest. These findings are aligned with previous studies [6,16,57-61]. On the other hand, we found that anxiety factor exhibits negative relationship with intend effort, ideal L2 self, family influence, attitudes towards language learning, attitudes towards L2 community, and cultural interest. These findings are aligned with previous studies $[62,63]$. The results also indicate that anxiety has a positive correlation with ought to L2 self and instrumentality motivation $[58,59,64]$. Table 5 shows correlation matrix of CFA.

\section{Discussion}

The purpose of this study was to translate and validate the instrument from Taguchi et al. [16] questionnaire measuring motivational factors of college-level L2 learners in a Korean context. In this validation study, several adaptations were made. First, one of the major findings is that all factors from Taguchi et al. [16] were identified except integrativeness. The items from integrativeness did not show any factor loading. Previous research, e.g., [11], also indicated that integrativeness did not reach the threshold in their 
item consistency analysis. Moreover, integrativeness shares similar meaning with ideal L2 self as a result from Taguchi et al. [16]. Theoretically, Dörnyei [7] proposed alternative framework, termed L2 motivational self-system, which suggested that integrativeness was not appropriate for foreign language context by questioning of Gardner's integrativeness theory of L2 learning motivation. Previous researchers [24,26] also argued that Gardner's integrativeness is hardly adaptable in a foreign language culture since it is more suitable for language learning within the target language community. With the statistical, theoretical, and empirical support, the integrativeness factor was deleted from our final model.

Second, we found that adjustment in translation and cultural adaptation in Korean context are much needed because participants may understand the translated questions in a different way due to the linguistic and cultural differences between Korean and English. Cross loading and dual loading were detected in this study, likely due to ambiguity or cultural difference. For example, item 58 ("Do you like to travel to English-speaking countries" [16], p. 96) asks both attitudes on L2 community and travel orientation. Originally, this question is intended to ask whether participants are interested in traveling to "L2 country." However, participants can perceive this question with a focus on "traveling" to L2 country because they are learning L2 language for tourism purpose. The questions containing nuance, which is culturally embedded, can be perceived differently by Korean students. Some items have to be moved to another factor or deleted due to an adjustment to the Korean context.

Previous research also involved translation and/or cultural adaptation adjustment problem in EFL context because of their native language characteristics [9,11]. One of the results from Tong et al. [9] found that two items were loaded onto one factor in their revised instrument due to the double negation sentence which is common in Chinese language characteristic. When Dörnyei [11] developed the questionnaire of Taguchi et al. [16], he developed the questionnaire for Iranian and Chinese contexts followed by a Japanese version. Dörnyei [11] indicated that even though they translated the items from the original version of questionnaire into Japanese, Chinese, and Farsi, it was necessary to modify or rewrite the items due to the different social milieu and the participant's learning environment adaptation. Thus, it was indispensable to adjust the items to load on different factors or delete them to fit into the Korean context.

Lastly, we found that items from family and ought-to L2 self were cross loaded. This means that it is difficult to differentiate the factor of motivational origin between family influence and ought-to L2 self. From the results of EFA, item 31("Being successful in English is important to me so that I can please my parents/relatives" [16], p. 93) is theoretically loaded on family factor. However, this item is loaded on both ought-to L2 self and family factors in my model. Similar to this, CFA modification also provided that item 32 ("I must study English to avoid being punished by my parents/relatives [16], p. 93) could be loaded on both family and ought-to L2 self factors. This can be explained by the Korean culture and the way that students' extrinsic motivation can be derived from their parent's wish or command [65]. To have a high salary job or be successful in their academic career, students and their parents from Korea place an emphasis on learning, with an expectation that students will enter prestigious universities [66,67]. It is reported that students from South Korea perceive their parents' role for educating them as both encouragement and pressure [68]. Hence, it is hard to differentiate between students' outsources motivation and parents' pressure in Korea because students connect their motivation pressure with parents' desire. This has been shown in similar results in Taguchi et al. [16]. Based on their statistical results, they combined ought-to L2 self with family influence factor because ought-to L2 self refers to friend, colleagues, and family at the same time. Taguchi et al. [16] indicated that Chinese students were forced to study by their parents to obtain more decent jobs and salary. However, in this study, we still keep family influence and ought-to L2 self separately because other items are loaded on their original factors with high value and identified through EFA even though some items were cross loaded. 


\section{Conclusions}

Through this research, the L2 motivational questionnaire from Taguchi et al. [16] was translated into Korean and validated among college students to measure their English learning motivation. We validated the questionnaire through back-translation approach followed by a pilot study. The findings in this chapter imply that integrativeness is one of the L2 motivational factors that has be considered carefully for future researchers who will study L2 motivation in EFL context. Moreover, this study confirmed that the questionnaire from Taguchi et al. [16] is structurally well established. Two factors were cross loaded due to the similar motivational origins, which are family and ought to L2 self. This has been interpreted as these motivations being interchangeable by characteristics of Korean culture because ought to L2 self can be caused by family. Additionally, this study offers a validated L2 motivation instrument with reduced number of items in Korean context which can be used in future research to measure L2 motivation among native Korean students.

\section{Limitations and Implications}

This study did not include the other L2 motivational factors (e.g., willingness to communicate) that were previously adopted in other studies. This is because some of the motivational factors were not originally included in the questionnaire from Taguchi et al. [16] which we validated in Korean college context and removed (e.g., ethnocentrism) during the content validity process due to the irrelevance of our study. For future work, we suggest that researchers may include other L2 motivational factors for validation that have not been covered in this study. In addition, this questionnaire has only been tested among college students in Korean context. Future researchers may want to apply it among other participants such as K-12 students or other adult language learners to examine the L2 motivational measurement model. Another limitation of this research is that even though the overall participants cover a variety of majors from different schools, some schools only include participants from one or two majors. This limitation stems from geographical limitations in that the researcher can only access participants who were willing to participate voluntarily.

This study implies that in cross-culture research, a questionnaire should be developed or modified according to the target population and their cultural and linguistic characteristics. This process suggests to future researchers who would like to validate a questionnaire for their target population or context that they should be aware that questionnaires should be adequately modified and reframed to fit the research purpose and cultural/linguistic context.

Author Contributions: Conceptualization, W.S. and F.T.; methodology, W.S., F.T., H.-Y.C. and M.Y.; software, W.S. and H.-Y.C.; validation, W.S., F.T., H.-Y.C. and M.Y.; formal analysis, W.S. and H.Y.C.; investigation, W.S., F.T., H.-Y.C. and M.Y.; resources, W.S.; data curation, W.S., F.T., and H.Y.C.; writing—original draft preparation, W.S.; writing—review and editing, W.S., F.T. and H.-Y.C.; supervision, F.T. and M.Y.; project administration, W.S., F.T., H.-Y.C. and M.Y.; All authors have read and agreed to the published version of the manuscript.

Funding: This research received no external funding.

Institutional Review Board Statement: The study was conducted according to the guidelines of the Declaration of Helsinki, and approved by the Institutional Review Board of Texas A\&M University (IRB20181115 and 11/26/2018).

Informed Consent Statement: Informed consent was obtained from each participant.

Conflicts of Interest: The authors declare no conflict of interest. 


\section{Appendix A}

Original Version of L2 Motivational Questionnaire in Korean Context (English).

\section{Questionnaire for L2 motivation and L2 profi-}

\section{ciency}

1. Gender $(\mathrm{M})(\mathrm{F})$

2. Department () Major ( )

3. When were you born? ()

4. What year are you in your school? ( )

5. Please write your score if you have taken one of the tests below TOEIC, ( ) TOEIC speaking and writing ( )

\begin{tabular}{lll} 
TOEFL (PBT, & ), TOEFL (CBT $\quad$ ), TOEFL (IBT \\
IELTs ( & ) \\
\hline
\end{tabular}

1. Have you ever studied abroad? (), If yes, which country have you visited and how long have you stayed in the country? ( )

Please read carefully and check one of the answers that you agree with. Choose 1 if you "strongly disagree", choose 2 if you "disagree", choose 3 if you feel neutral, choose 4 if you "agree", and choose 5 if you "strongly agree."

\begin{tabular}{|c|c|}
\hline Number & Questions \\
\hline 1. & If an English course was offered in the future, I would like to take it. \\
\hline 2. & $\begin{array}{l}\text { If my teacher would give the class an optional assignment, I would certainly volunteer } \\
\text { to do it. }\end{array}$ \\
\hline 3. & I would like to study English even if it is not required. \\
\hline 4. & I would like to spend lots of time studying English. \\
\hline 5. & I would like to concentrate on studying English more than any other topic. \\
\hline 6. & I am prepared to expend a lot of effort in learning English. \\
\hline 7. & I am working hard at learning English \\
\hline 8. & Compared to my classmates, I think I study English relatively hard. \\
\hline 9. & $\begin{array}{l}\text { I can imagine myself studying in a university where all my courses are taught in } \\
\text { English. }\end{array}$ \\
\hline 10. & Whenever I think of my future career, I imagine myself using English. \\
\hline 11. & I can imagine myself speaking English with international friends or colleagues. \\
\hline 12. & $\begin{array}{l}\text { I can imagine myself living abroad and using English effectively for communicating } \\
\text { with the locals. }\end{array}$ \\
\hline 13. & I can imagine myself speaking English as if I were a native speaker of English. \\
\hline 14. & I imagine myself as someone who is able to speak English. \\
\hline 15. & I can imagine myself writing English e-mails/letters fluently. \\
\hline 16. & I study English because close friends of mine think it is important. \\
\hline 17. & Learning English is necessary because people surrounding me expect me to do so. \\
\hline 18. & $\begin{array}{l}\text { I consider learning English important because the people I respect think that I should } \\
\text { do it. }\end{array}$ \\
\hline 19. & If I fail to learn English I'll be letting other people down. \\
\hline 20. & $\begin{array}{l}\text { Studying English is important to me in order to gain the approval of } \\
\text { mypeers/teachers/family/boss. }\end{array}$ \\
\hline 21. & $\begin{array}{l}\text { Studying English is important to me because an educated person is supposed to be } \\
\text { able to speak English. }\end{array}$ \\
\hline
\end{tabular}




\begin{tabular}{|c|c|}
\hline Number & Questions \\
\hline 22. & $\begin{array}{l}\text { Studying English is important to me because other people will respect me more if I } \\
\text { have a knowledge of English. }\end{array}$ \\
\hline 23. & It will have a negative impact on my life if I don't learn English. \\
\hline 24. & My parents encourage me to study English in my free time. \\
\hline 25. & $\begin{array}{l}\text { My parents encourage me to take every opportunity to use my English(e.g., speaking } \\
\text { and reading). }\end{array}$ \\
\hline 26. & My parents encourage me to practice my English as much as possible. \\
\hline 27. & $\begin{array}{l}\text { My parents encourage me to attend extra English classes after class (e.g., at English } \\
\text { conversation schools). }\end{array}$ \\
\hline 28. & My family put a lot of pressure on me to study English. \\
\hline 29. & My parents/family believe(s) that I must study English to be aneducated person. \\
\hline 30. & Studying English is important to me in order to bring honor to my family. \\
\hline 31. & $\begin{array}{l}\text { Being successful in English is important to me so that I can pleasemy } \\
\text { parents/relatives. }\end{array}$ \\
\hline 32. & I must study English to avoid being punished by my parents/relatives. \\
\hline 33. & $\begin{array}{l}\text { I have to study English, because, if I don't do it, my parents will be disappointed with } \\
\text { me. }\end{array}$ \\
\hline 34. & $\begin{array}{l}\text { Studying English can be important to me because I think it will someday be useful in } \\
\text { getting a good job }\end{array}$ \\
\hline 35. & $\begin{array}{l}\text { Studying English is important to me because English proficiency is necessary for } \\
\text { promotion in the future. }\end{array}$ \\
\hline 36. & Studying English is important to me because with English I can work globally. \\
\hline 37. & $\begin{array}{l}\text { Studying English is important because with a high level of English proficiency, I will } \\
\text { be able to make a lot of money. }\end{array}$ \\
\hline 38. & $\begin{array}{l}\text { Studying English can be important to me because I think I will need it forfurther } \\
\text { studies in my major. }\end{array}$ \\
\hline 39. & $\begin{array}{l}\text { Studying English is important to me because I would like to spend a longer period } \\
\text { living abroad (e.g., studying and working) }\end{array}$ \\
\hline 40. & I study English in order to keep updated and informed of recent news of the world. \\
\hline 41. & $\begin{array}{l}\text { Studying English is important to me because in order to achieve a special goal (e.g., to } \\
\text { get a degree or scholarship). }\end{array}$ \\
\hline 42. & Studying English is important to me in order to attain a higher level ofsocial respect. \\
\hline 43. & Studying English is important to me because it offers a new challenge in my life. \\
\hline 44. & The things I want to do in the future require me to use English. \\
\hline 45. & I have to learn English because without passing the English course I cannot graduate. \\
\hline 46. & I have to learn English because I don't want to fail the English course. \\
\hline 47. & I have to study English because I don't want to get bad marks in it at university. \\
\hline 48. & $\begin{array}{l}\text { Studying English is necessary for me because I don't want to get a poor score or a fail } \\
\text { mark in English proficiency tests. }\end{array}$ \\
\hline 49. & I have to study English; otherwise, I think I cannot be successful in myfuture career. \\
\hline 50. & $\begin{array}{l}\text { Studying English is important to me, because I would feel ashamed if I gotbad grades } \\
\text { in English. }\end{array}$ \\
\hline 51. & $\begin{array}{l}\text { Studying English is important to me because, if I don't have knowledge of English, I } \\
\text { will be considered a weak learner. }\end{array}$ \\
\hline 52. & I like the atmosphere of my English classes. \\
\hline 53. & I always look forward to English classes. \\
\hline 54. & I find learning English really interesting. \\
\hline 55. & I really enjoy learning English. \\
\hline 56. & Do you think time passes faster while studying English? \\
\hline 57. & Would you like to have more English lessons at school? \\
\hline 58. & Do you like to travel to English-speaking countries? \\
\hline 59. & Do you like the people who live in English-speaking countries? \\
\hline 60. & Do you like meeting people from English-speaking countries? \\
\hline
\end{tabular}




\begin{tabular}{ll}
\hline Number & \multicolumn{1}{c}{ Questions } \\
\hline 61. & Would you like to know more about people from English-speaking countries? \\
62. & Do you like the music of English-speaking countries (e.g., pop music?) \\
63. & Do you like English films? \\
64. & Do you like English magazines, newspapers, or books? \\
65. & Do you like TV programs made in English speaking countries? \\
66. & I get nervous and confused when I am speaking in my English class. \\
67. & I would feel uneasy speaking English with a native speaker \\
68. & If I met an English native speaker, I would feel nervous. \\
69. & I would get tense if a foreigner asked me for directions in English \\
70. & I am worried that other speakers of English would find my English strange. \\
71. & How important do you think learning English is in order to learn more about the \\
72. & culture and art of its speakers? \\
73. & How much would you like to become similar to the people who speak English? \\
74. & Learning do you like English? \\
75. & Studying English is important to me because I would like to travel internationally. \\
76. & a lot. \\
\hline
\end{tabular}

\section{Appendix B}

Original Version of L2 Motivational Questionnaire in Korean Context.

\section{영어학습동기에 관한 설문조사}

1. 귀하의 성별을 표시해주세요. (남) (여)

2. 학부 () 전공 ()

3. 귀하는 몇 년 도에 태어났습니까? ()

4. 귀하는 현재 몇 학기째 학교를 다니고 있습니까? ()

5. 귀하는 아래에 해당하는 영어표준 시험을 본적이 있습니까? 있으면 점수를 적어주 세요

TOEIC, ( )

TOEIC speaking and writing ( )

TOEFL (PBT,), TOEFL (CBT), TOEFL (IBT)

$\operatorname{IELTs}($ )

6. 귀하는 어학연수 또는 학업을 해외에서 하신적이 있습니까? ()

있다면 어느 지역에서 얼마나 체류하셨습니까? ( )

아래 각각의 문장을 읽고 해당되는 사항에 1-5 중 하나에 표시해 주십시요. "전혀 그렇 지 않다" 는 1 번, "그렇지 않다" 는 2번, "보통이다" 는 3번, "그런편이다" 는 4 번, "매우 그 렇다" 는 5번에 표시해주세요. 


\begin{tabular}{|c|c|}
\hline 문항 & 설문내용 \\
\hline 1. & 만일 미래에 영어강좌가 개설된다면 나는 들을 것이다. \\
\hline 2. & 만일 선생님이 선 택적인 숙제를 내어 준다면 나는 기꺼이 숙제를 할 것이다. \\
\hline 3. & 나는 필수사항이 아니더래도 영어공부를 할 것이다. \\
\hline 4. & 나는 영어공부에 많은 시간을 쓸 것이다. \\
\hline 5. & 나는 다른 주제 보다 영어공부하는것에 집중하고 싶다. \\
\hline 6. & 나는 영어공부를 하는데 많은 노력을 할 준비가 되어있다. \\
\hline 7. & 나는 영어공부하는데 최선을 다 한다고 생각한다. \\
\hline 8. & 다른 학생에 비해서 상대적으로 내가 영어공부를 보다 더 열 심히 한다고 생각한다. \\
\hline 9. & 모든 수업이 영어로 진행되는 대학교 수업을 듣고 있는 내 모습을 떠올린다. \\
\hline 10. & 미래의 내 직장을 생각하면 나는 영어를 쓰고 있는 나 자신을 생각하게 된다. \\
\hline 11. & 나는 외국인 친구나 동료와 영어로 이야기 하는 내 모습을 생각한다. \\
\hline 12. & 나는 외국에 살면서 그 곳 사람들과 영어로 이야기 하는 내 모습을 생각한다. \\
\hline 13. & 나는 내가 마치 원어민 선생님처럼 영어를 잘 사용하는 모습을 생각한다. \\
\hline 14. & 내가 영어를 잘 말 할 수 있는 사람이 될 것이라고 상상한다. \\
\hline 15. & 나 스스로가 영어로 유창하게 이메일이나 편지를 쓰는것을 생각한다. \\
\hline 16. & 나는 친한 친구들이 영어가 중요하다고 생각하기 때문에 영어를 공부한다. \\
\hline 17. & 내 주위 사람들이 나에대한 기대가 있기 때문에 영어공부는 필요하다. \\
\hline 18. & $\begin{array}{l}\text { 내가 존경하는 사람들이 내가 영어공부를 해야한다고 하기 때문에 중요하다고 생각한 } \\
\text { 다. }\end{array}$ \\
\hline 19. & 내가 영어를 배우는데 실패를 하면 다른 사람들은 실망 할 것이다. \\
\hline 20. & 내 친구나 선생님, 가족, 윗사람들로부터 인정받이 위해서 영어공부는 중요하다. \\
\hline 21. & $\begin{array}{l}\text { 교육받은 사람은 영어로 말을 잘 해야하기 때문에 나에게 영어공부를 하는 것은 중요하 } \\
\text { 다. }\end{array}$ \\
\hline 22. & 내가 영어를 잘 하면 사람들이 나를 존경하기 때문에 영어공부는 중요하다 \\
\hline 23. & 만일 내가 영어를 공부하지 않으면 내 인생에 안 좋은 영향이 있을 것이다. \\
\hline 24. & 내 부모님은 내가 시간이 날 때 영어공부를 하도록 하신다 \\
\hline 25. & 내 부모님은 기회가 있으면 영어를 사용하도록 하신다. (말하기 \\
\hline 26. & 내 부모님은 내가 영어를 가능 한 많이 연습하도록 하신다 \\
\hline 27. & 내 부모님은 내가 수업 이 외의 영어보충 수업에 참여하도록 장려하신다 (영어회화수업) \\
\hline 28. & 우리 가족은 영어공부하는데 많은 압력을 주신다. \\
\hline 29. & 내 부모님/가족은 내가 교육받은 사람이 되기 위해서 영어를 배워야 한다고 생각하신다. \\
\hline 30. & 우리 가족에게 명예를 가져와야 하기 때문에 영어공부는 나에게 중요하다. \\
\hline 31. & $\begin{array}{l}\text { 내 부모나 친척을 기쁘게 해주기 위해 영어공부를 성공적이게 하는것은 나에게 중요 } \\
\text { 하다 }\end{array}$ \\
\hline 32. & 내 부모나 가족에게 벌을 받지 않기 위해 나는 영어공부를 해야만 한다. \\
\hline 33. & $\begin{array}{l}\text { 나는 영어공부를 해야한다, 그렇지 않으면 우리 부모님은 나에게 실망하실것이기 때문 } \\
\text { 이다. }\end{array}$ \\
\hline 34. & $\begin{array}{l}\text { 영어가 언젠가는 좋은 직업을 잡는데 필요할 것이라고 생각하기에 영어공부는 나에게 } \\
\text { 중요하다. }\end{array}$ \\
\hline 35. & 미래에 승진하는데 영어실력이 필요하기 때문에 영어공부는 중요하다. \\
\hline 36. & 나는 글로 벌하게 일하고 싶기때문에 영어공부는 중요하다. \\
\hline 37. & 영어실력이 좋은면 돈을 많이 벌 수 있기 때문에 영어공부는 중요하다. \\
\hline 38. & 내 전공에 대해 더 공부할 때 필요할 수 있기 때문에 영어공부는 중요하다. \\
\hline 39. & 해외에서 살고 싶기때문에 영어공부는 필요하다. (유학이나 업무로 인해) \\
\hline 40. & 전 세계에서 일어나는 일들을 알기 위해 영어공부를 한다. \\
\hline 41. & 특별한 목적을 달성하기 위해 영어공부는 중요하다. (학위나 장학금을 따기위해) \\
\hline 42. & 높은 사회적인 직위를 얻기위해 영어공부는 중요하다. \\
\hline 43. & 내 삶에 새로운 도전을 위해 영어공부는 중요하다. \\
\hline 44. & 내가 미래에 하고 싶은 일은 영어가 필요한 일이다. \\
\hline 45. & 영어수업을 듣지 않으면 졸업을 못하기 때문에 영어를 공부해야 한다. \\
\hline
\end{tabular}




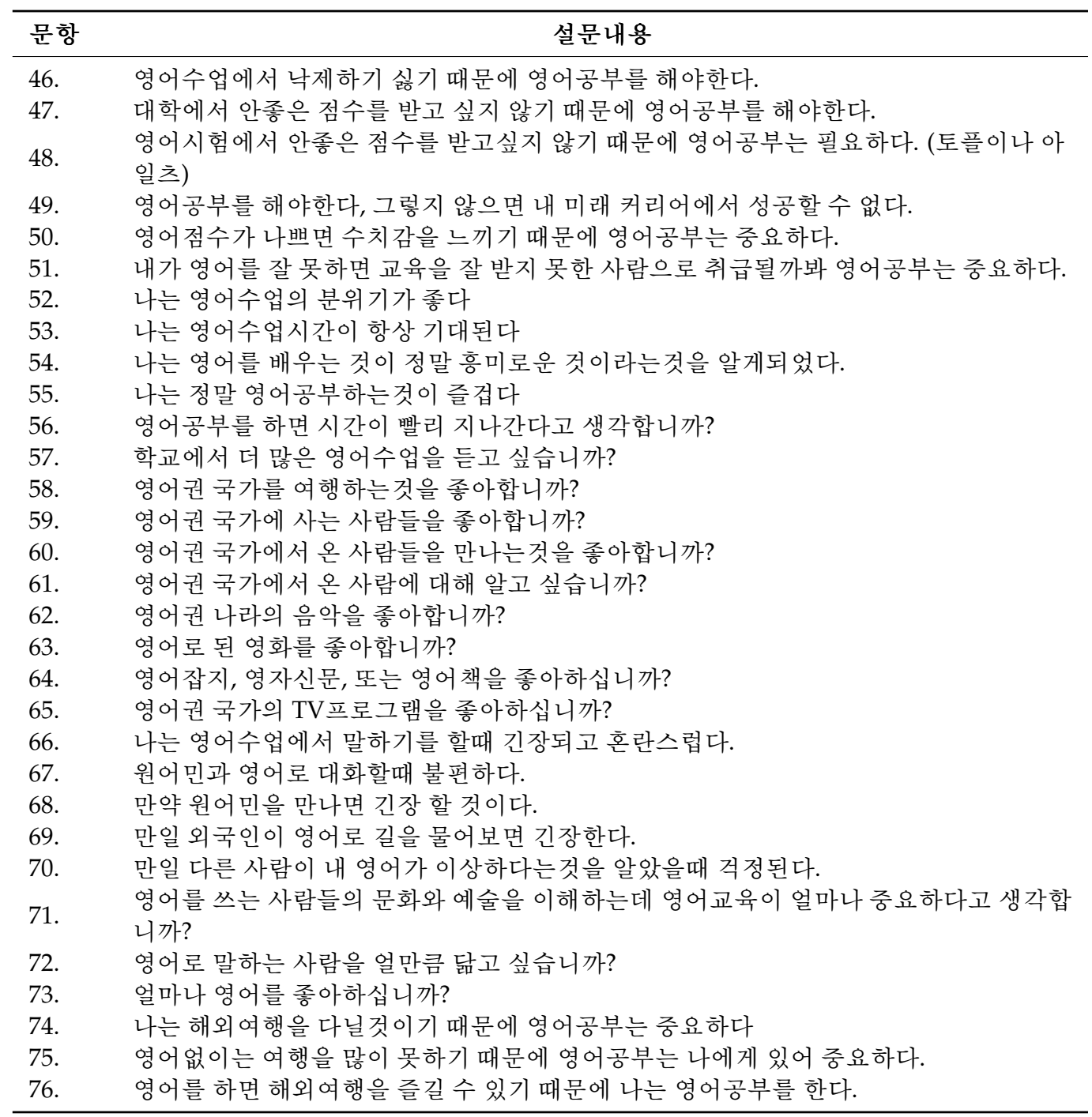

\section{References}

1. Nunan, D. The impact of English as a global language on educational policies and practices in the Asia-Pacific Region. TESOL Q. 2012, 37, 589-613. [CrossRef]

2. Park, J. English fever in South Korea: Its history and symptoms. Engl. Today 2009, 25, 50-57. [CrossRef]

3. Eom, M.; Lang, Y.; Xie, C. Chinese and Korean college students' perceptions of standardized English tests. Asian J. Appl. Linguist. 2017, 4, 117-128.

4. Jee, S.; Kim, H. Understanding English learners preparing for TOEIC and their information technology usage practices in Korea. Int. J. Multimed. Ubiquitous Eng. 2013, 8, 93-104. [CrossRef]

5. Korean Statistical Information Service. Private Education Expenditure Survey. 2016. Available online: http://kostat.go.kr/ portal/eng/surveyOutline/5/2/index.static (accessed on 20 June 2019).

6. Ghanizadeh, A.; Rostami, S. A Dörnyei-inspired study on second language motivation: A cross-comparison analysis in public and private contexts. Psychol. Stud. 2015, 60, 292-301. [CrossRef]

7. Dörnyei, Z. The Psychology of the Language Learner: Individual Differences in Second Language Acquisition; Erlbaum: Mahwah, NJ, USA, 2005.

8. Meechai, A.K. An Investigation of the Internal Motivational Structure of ESL Students at the Community College. Ph.D. Thesis, University of Kansas, Lawrence, KS, USA, 1998.

9. Tong, F.; Guo, H.; Wang, Z.; Min, Y.; Guo, W.; Yoon, M. Examining cross-cultural transferability of self-regulated learning model: An adaptation of the motivated strategies for learning questionnaire for Chinese adult learners. Educ. Stud. 2019, 46, 422-439. [CrossRef]

10. Kormos, J.; Csizér, K. Age-Related differences in the motivation of learning English as a foreign language: Attitudes, selves, and motivated learning behavior. Lang. Learn. 2008, 58, 327-355. [CrossRef]

11. Dörnyei, Z. Researching motivation: From integrativeness to the ideal L2 self. In Introducing Applied Linguistics: Concepts and Skills; Hunston, S., Oakey, D., Eds.; Routledge/Taylor Francis: New York, NY, USA, 2010; pp. 74-83. 
12. Lee, H.; Lee, J. Who gets the best grades at top universities? An exploratory analysis of institution-wide interviews with the highest achievers at a top Korean university. Asia Pac. Educ. 2012, 13, 665-676. [CrossRef]

13. Munezane, Y. A Structural Equation Model and Intervention Study of Individual Differences, Willingness to Communicate, and L2 Use in an EFL Classroom. Doctoral Dissertation, Temple University, Philadelphia, PA, USA, 2014.

14. Teimouri, Y. L2 selves, emotions and motivated behavior. Stud. Second Lang. Acquis. 2017, 39, 681-709. [CrossRef]

15. Lau, K. Construction and initial validation of the Chinese reading motivation questionnaire. Educ. Psychol. 2004, 24, 845-865. [CrossRef]

16. Taguchi, T.; Magid, M.; Papi, M. The L2 motivational self system among Japanese, Chinese and Iranian learners of English: A comparative study. In Motivation, Language Identity and the L2 Self; Dörnyei, Z., Ushioda, E., Eds.; Multilingual Matters: Bristol, UK, 2009; pp. 66-97.

17. Lockwood, P.; Marshall, T.C.; Sadler, P. Promoting success or preventing failure: Cultural differences in motivation by positive and negative role models. Personal. Soc. Psychol. Bull. 2005, 31, 379-392. [CrossRef]

18. Kim, T.; Kim, Y. A structural model for perceptual learning styles, the ideal L2 self, motivated behavior, and English proficiency. System 2014, 46, 14-27. [CrossRef]

19. Cohen, A.; Oxford, R.L. Learning Style Survey for Young Learners; Center for Advanced Research on Language Acquisition: Minneapolis, MN, USA, 2001. Available online: http://www.tc.umn.edu/ \{\}adcohen/publications.html\#strategies (accessed on 6 August 2018).

20. Kinsella, K. Perceptual learning preferences survey. In Learning Styles in the ESL/EFL Classroom; Reid, J.M., Ed.; Heinle and Heinle: Boston, MA, USA, 1995; pp. 221-238.

21. Al-Shehri, A.H. Motivation and vision: The relation between the ideal L2 self, imagination and visual style. In Motivation, Language Identity and the L2 Self; Dörnyei, Z., Ushioda, E., Eds.; Multilingual Matters: Bristol, UK, 2009; pp. $164-171$.

22. Kim, T.; Kim, Y. The impact of resilience on L2 learners' motivated behavior and proficiency in L2 learning. Educ. Stud. 2016, 43, 1-15. [CrossRef]

23. Shin, W.Y.; Kim, M.G.; Kim, J.H. Developing Measures of Resilience for Korean Adolescents and Testing Cross, Convergent, and Discriminant Validity. Stud. Korean Youth 2009, 20, 105-131.

24. Kim, T.; Kim, Y.; Kim, J. Structural relationship between L2 learning (De)motivation, resilience, and L2 proficiency among Korean college students. Asia-Pac. Edu. Res. 2017, 26, 397-406. [CrossRef]

25. Lee, J.H.; Lo, Y.Y. An exploratory study on the relationships between attitudes toward classroom language choice, motivation, and proficiency of EFL learners. System 2017, 67, 121-131. [CrossRef]

26. Kim, T. The L2 motivational self system of Korean EFL students: Cross-grade survey analysis. Engl. Teach. 2012, 67, 29-56.

27. Macaro, E.; Lee, J.H. Teacher language background, codeswitching, and English-only instruction: Does age make a difference to learners' attitudes? TESOL Q. 2013, 47, 717-742. [CrossRef]

28. Rolin-Ianziti, J.; Varshney, R. Students' views regarding the use of the first language: An exploratory study in a tertiary context maximising target language use. Can. Mod. Lang. Rev. 2008, 65, 249-273. [CrossRef]

29. Thompson, A.S.; Erdil-Moody, Z. Operationalizing multilingualism: Language learning motivation in Turkey. Int. J. Biling. Educ. Biling. 2016, 19, 314-331. [CrossRef]

30. Roshandel, J.; Ghonsooly, B.; Ghanizadeh, A. L2 motivational self-system and self-efficacy: A quantitative survey-based study. Int. J. Instr. 2018, 11, 329-344. [CrossRef]

31. Ueki, M.; Takeuchi, O. Forming a clearer image of the ideal L2 self: The L2 motivational self system and learner autonomy in a Japanese EFL context. Innov. Lang. Learn. Teach. 2013, 7, 238-252. [CrossRef]

32. Moskovsky, C.; Racheva, S.; Assulaimani, T.; Harkins, J. The L2 motivational self system and L2 achievement: A study of Saudi EFL learners. Mod. Lang. J. 2016, 100, 641-654. [CrossRef]

33. Aubrey, S. Development of the L2 motivational self system: English at a University in Japan. JALT J. 2014, 36, 153-174. [CrossRef]

34. Kong, J.H.; Han, J.E.; Kim, S.; Park, H.; Kim, Y.S.; Park, H. L2 Motivational Self System, international posture and competitiveness of Korean CTL and LCTL college learners: A structural equation modeling approach. System 2018, 72, 178-189. [CrossRef]

35. Safdari, S. Validation of a tailored L2 motivational self system questionnaires through confirmatory factor analysis. Int. Online J. Educ. Teach. 2017, 4, 174-183.

36. Liu, Y.; Thompson, A.D. Language learning motivation in China: An exploration of the L2MSS and psychological reactance. System 2018, 72, 37-48. [CrossRef]

37. Dörnyei, Z.; Csizér, K. Some dynamics of language attitudes and motivation: Results of a longitudinal nationwide survey. Appl. Linguist. 2002, 23, 421-462. [CrossRef]

38. You, C.; Dörnyei, Z. Language Learning Motivation in China: Results of a Large-Scale Stratified Survey. Appl. Linguist. 2016, 37, 495-519. [CrossRef]

39. Dörnyei, Z.; Ushioda, E. Teaching and Researching Motivation; Longman: London, UK, 2001.

40. Kim, T. Korean elementary school students' perceptual learning style, ideal L2 self, and motivated behavior. Korean J. Engl. Lang. Linguist. 2009, 9, 461-485.

41. Brislin, R.W. Back translation for cross cultural research. J. Cross Cult. Psychol. 1970, 1, 185-216. [CrossRef] 
42. Lam, S.F.; Jimerson, S.; Wong, B.P.H.; Kikas, E.; Shin, H.; Veiga, F.H.; Hatzichristou, C.; Polychroni, F.; Cefai, C.; Negovan, V.; et al. Understanding and measuring student engagement in school: The results of an international study from 12 countries. Sch. Psychol. Q 2014, 29, 213-232. [CrossRef]

43. Cabrera-Nguyen, P. Author guidelines for reporting scale development and validation results in the journal of the society for social work and research. J. Soc. Soc. Work Res. 2010, 1, 99-103. [CrossRef]

44. Winter, J.C.F.; Dodou, D.; Wieringa, P.A. Exploratory factor analysis with small sample sizes. Multivar. Behav. Res. 2009, 44, 147-181. [CrossRef]

45. Rouquette, A.; Falissard, B. Sample size requirements for the internal validation of psychiatric scales. Int. J. Methods Psychiatr. Res. 2011, 20, 235-249. [CrossRef]

46. Furr, R.M.; Bacharach, V.R. Psychometrics: An Introduction, 2nd ed.; SAGE: Los Angeles, CA, USA, 2014. Available online: http:/ / p2048-lib-ezproxy.tamu.edu.ezproxy.library.tamu.edu/login?url=http:/ / search.ebscohost.com.ezproxy.library.tamu. edu/login.aspx?diredi=true\&db=cat03318a\&AN=tamug.4697136\&site=eds-live (accessed on 6 April 2018).

47. Weston, R.; Gore, P.A. A brief guide to structural equation modeling. Couns. Psychol. 2006, 34, 719-751. [CrossRef]

48. Byrne, B.M. Multivariate Applications Book Series. Structural Equation Modeling with LISREL, PRELIS, and SIMPLIS: Basic Concepts, Applications, and Programming; Lawrence Erlbaum Associates Publishers: Mahwah, NJ, USA, 1998.

49. Bishop, D.I.; Hertenstein, M.J. A confirmatory factor analysis of the structure of temperament questionnaire. Educ. Psychol. Meas. 2004, 64, 1-11. [CrossRef]

50. McDonald, R.P. Test Theory: A Unified Treatment; Psychology Press: New York, NY, USA, 2013.

51. Revelle, W.; Zinbarg, R.E. Coefficients alpha, beta, omega, and the glb: Comments on Sijtsma. Psychometrika 2009, 74, 145-154. [CrossRef]

52. Revelle, W. Psych: Procedures for Psychological, Psychometric, and Personality Research, R package version 2.1.6; Northwestern University: Evanston, IL, USA, 2021. Available online: https:/ /CRAN.R-project.org/package=psych (accessed on 6 April 2018).

53. Hu, L.; Bentler, P.M. Cutoff criteria for fit indexes in covariance structure analysis: Conventional criteria versus new alternatives. Struct. Equ. Modeling 1999, 6, 1-55. [CrossRef]

54. Tabachnick, B.G.; Fidell, L.S. Using Multivariate Statistics, 5th ed.; Pearson Education Inc.: London, UK, 2007.

55. MacCallum, R.C.; Roznowski, M.; Necowitz, L.B. Model modifications in covariance structure analysis: The problem of capitalization on chance. Psychol. Bull. 1992, 111, 490-504. [CrossRef] [PubMed]

56. Fornell, C.; Larcker, D.F. Evaluating structural equation models with unobservable variables and measurement error. J. Mark. Res. 1981, 18, 39-50. [CrossRef]

57. Ryan, S. The Ideal L2 Selves of Japanese Learners of English; University of Nottingham: Nottingham, UK, 2008.

58. Papi, M. The L2 motivational self-system, L2 anxiety, and motivated behavior: A structural equation modeling approach. System 2010, 38, 467-479. [CrossRef]

59. Alqahtani, A.F. English language learning motivation and English language learning anxiety in Saudi military cadets: A structural equation modeling approach. Arab. World Engl. J. 2018, 9, 45-60. [CrossRef]

60. Noels, K.A. Learning Spanish as a second language: Learners' orientations and perceptions of their teachers' communication style. In Attitudes, Orientations, and Motivations in Language Learning; Dörnyei, Z., Ed.; Blackwell: Oxford, UK, 2003 ; pp. 97-136.

61. Lai, H.T. The motivation of learners of English as a foreign language revisited. Int. Educ. Stud. 2013, 6, 90-101. [CrossRef]

62. Jain, Y.; Sidhu, G.K. Relationship between anxiety, attitude and motivation of tertiary students in learning English as a second language. Procedia-Soc. Behav. Sci. 2013, 90, 114-123. [CrossRef]

63. Chun, S.; Kim, H.; Park, C.; McDonald, K.; Ha, O.S.; Kim, D.L.; Lee, S.M. South Korean students' responses to English-medium instruction courses. Soc. Behav. Personal. 2017, 45, 951-966. [CrossRef]

64. Madkhali, A. A Study of the L2 Motivational Self-System in an ESL Intensive Context among Saudi Arabian Students. Master's Thesis, Faculty of St. Cloud State University, ST. Cloud, MN, USA, 2016; p. 67.

65. Liu, Y.; Park, H. A Study of Korean EFL Learners' WTC and Motivation. J. Pan-Pac. Assoc. Appl. Linguist. 2012, $16,35-58$.

66. Jang, S. Hakryeokseongchio'ui Gyegeupbyeol, Seongbyeol Chai. [The difference of educational degree among class and gender]. Korean J. Sociol. 2004, 38, 51-75.

67. Zeng, K. Japan's dragon gate. The effects of university entrance examination on the educational systems and students. Compare 1995, 25, 59-83. [CrossRef]

68. Moris, A. Affective variables, parental involvement and competence among South Korean high school learners of English. Stud. Second Lang. Learn. Teach. 2013, 3, 13-45. [CrossRef] 